Revista Brasileira de Agricultura Irrigada v.12, nº.6, p. 3058 - 3068, 2018

ISSN 1982-7679 (On-line)

Fortaleza, CE, INOVAGRI - http://www.inovagri.org.br

DOI: $10.7127 /$ rbai.v12n6001010

Protocolo 1010.18 - 31/08/2018 Aprovado em 13/01/2019

\title{
MORPHOLOGICAL AND PHYSIOLOGICAL TRAITS OF UPLAND RICE CULTIVARS AFFECTED BY WATER DEFICIT
}

\author{
Cleber Morais Guimarães ${ }^{1}$, Luís Fernando Stone ${ }^{2}$, Pedro Marques da Silveira ${ }^{3}$
}

\begin{abstract}
The use of drought-tolerant cultivars is a promising strategy to minimize the effects of water deficits on upland rice productivity. Therefore, it is important to establish an adequate methodology to evaluate the performance of upland rice cultivars under water deficit. In this study, one evaluated the effects of water deficit on morphological and physiological traits of two upland rice cultivars, in a greenhouse, in soil columns, using a phenotyping platform named SITIS. The experiment occurred in a complete randomized block design, in a split plot scheme with four replications. The main plots consisted of a well-irrigated treatment with daily replacement of $100 \%$ evapotranspired water and four water restriction regimes (daily replacement of $20 \%, 40 \%, 60 \%$ and $80 \%$ evapotranspired water at the well-irrigated treatment) and, the subplots, of the Douradão and BRS Soberana cultivars, which are tolerant and sensitive to water stress, respectively. It is feasible to use the SITIS platform and the proposed protocol (water regimes) to evaluate upland rice cultivars for tolerance to water stress. Under water deficit, the Douradão cultivar restricted its transpiration and showed harvest index, grain yield and water use efficiency higher than the BRS Soberana cultivar.
\end{abstract}

Keywords: Oryza sativa L., phenotyping platform, leaf water potential, leaf diffusive resistance, leaf temperature.

\section{CARACTERÍSTICAS MORFOLÓGICAS E FISIOLÓGICAS DE CULTIVARES DE ARROZ DE TERRAS ALTAS AFETADAS PELA DEFICIÊNCIA HÍDRICA}

\section{RESUMO}

O uso de cultivares tolerantes é uma estratégia promissora para minimizar os efeitos de déficits hídricos na produtividade do arroz de terras altas. Assim, é importante estabelecer uma metodologia adequada para a avaliação da performance de cultivares de arroz de terras

\footnotetext{
${ }^{1}$ Doutor em Biologia Vegetal, Pesquisador, Embrapa Arroz e Feijão. Santo Antônio de Goiás-GO. Email: cleber.guimaraes@embrapa.br

${ }^{2}$ Doutor em Solos e Nutrição de Plantas, Pesquisador, Embrapa Arroz e Feijão. Santo Antônio de Goiás-GO. Email: luis.stone@embrapa.br

${ }^{3}$ Doutor em Solos e Nutrição de Plantas, Pesquisador, Embrapa Arroz e Feijão. Santo Antônio de Goiás-GO. Email: pedro.silveira@embrapa.br
} 
altas sob déficit hídrico. Neste estudo, foram avaliados os efeitos do déficit hídrico nas características morfológicas e fisiológicas de duas cultivares de arroz, em casa de vegetação, em colunas de solo, usando uma plataforma de fenotipagem denominada SITIS. Foi usado o delineamento de blocos casualizados completos, em parcelas subdivididas, com quatro repetições. Nas parcelas foram dispostos um tratamento bem irrigado, com reposição diária de $100 \%$ da água evapotranspirada, e quatro regimes de restrição hídrica (reposição diária de $20 \%, 40 \%, 60 \%$ e $80 \%$ da água evapotranspirada no tratamento bem irrigado) e, nas subparcelas, as cultivares Douradão e BRS Soberana, que são consideradas tolerante e sensível ao déficit hídrico, respectivamente. É possível usar a plataforma SITIS e o protocolo proposto (regimes hídricos) para avaliar cultivares de arroz quanto à tolerância à deficiência hídrica. Sob deficiência hídrica, a cultivar Douradão restringiu a transpiração e apresentou maiores índice de colheita, produtividade e eficiência do uso da água do que a BRS Soberana.

Palavras-chave: Oryza sativa L., plataforma de fenotipagem, potencial hídrico foliar, resistência difusiva foliar, temperatura foliar.

\section{INTRODUCTION}

Water stress reduces upland rice yield, even in regions with low risk of drought, because the occurrence of dry spells is common, when rainfall cannot meet the crop demand (GUIMARÃES et al., 2010). The upland rice ancestors were semi-aquatic and it is not yet fully adapted to the aerobic systems, because of its limited tolerance to water stress compared with other upland crops. Nevertheless, the upland rice must adapt to water stresses similarly to other crops such as soybeans and corn; otherwise, it will not be feasible in crop rotation systems (GUIMARÃES et al., 2013).

The use of drought-tolerant cultivars is a promising strategy to minimize the effects of water deficits during the rainy season on upland rice productivity (HEINEMANN et al., 2011). Dry spells are unpredictable; thus, the drought tolerance in rice genotypes should be treated as a trait to be observed in the selection of superior genotypes. As the ability of plants to grow roots according to the distribution of available soil water profoundly increases plant productivity under drought, a deep root system with higher root density is likely to be useful if the growing conditions permit root development at depth (COMAS et al., 2013).

Water stress tolerance, among other factors, results from the maintenance of good water status in plant tissues, which can be evaluated by leaf water potential, leaf diffusive resistance and leaf temperature (GUIMARÃES et al., 2015). These authors related that the maintenance of leaf water potential could explain the best productivity of upland rice genotypes under water stress, before and after the emergence of panicles, which improved the overall water condition of the plants.

The use of managed water stress, where it can be imposed at specific periods, has been shown to increase the heritability of yield under stress to values similar to those obtained for yield in wellwatered conditions. According to Kumar et al. (2014), in large mapping populations, the correlation between high yield potential and good yield under drought was low but always positive, suggesting the possibility to combine high yield potential and good yield under drought successfully. Consequently, the directly selection for yield in stress environments can breed droughttolerant upland rice (KUMAR et al., 2014). Therefore, a precision phenotyping for drought response is a vital step before implementing the genetic and molecular-physiological strategies to unravel the complex multilayered drought tolerance mechanism and further exploration using molecular approaches for crop breeding (MIR et al., 2012). In this sense, the capacity for precise phenotyping under reliable conditions probably represents the most limiting factor for the progress of genomic studies on drought tolerance. Great precision is required because the differences may be small and subtle, and detailed physiological measurements are difficult when involving many genotypes (ARAUS; CAIRNS, 2014). Phenotyping platforms were developed aimed at accurate phenotyping, with a large-scale and automated assessment. These platforms are useful tools for identifying agronomic and physiological traits that can be assessed in a 
fast and/or non-destructive manner and that have a strong correlation with crop yield under waterstress conditions, such as leaf water potential, leaf diffusive resistance and leaf temperature (GUIMARÃES et al., 2015). This study aimed to evaluate the effects of water deficit on morphological and physiological traits of two upland rice cultivars, in a greenhouse, in soil columns, using a phenotyping platform named SITIS and a specific protocol (different percentages of daily replacement of evapotranspired water).

\section{MATERIAL AND METHODS}

The study took place in a greenhouse, at Embrapa Arroz e Feijão, in Santo Antônio de Goiás, GO, Brazil (16²7'28"S, 49¹9'52"W, at 823 $\mathrm{m}$ above sea level).

A phenotyping platform for tolerance to water stress named "SITIS", which is a real-time automated control system for monitoring plant physiological parameters, soil moisture, greenhouse climate and irrigation of the soil columns were used. It is composed of 384 soil columns, packed in PVC pipes with a $0.25 \mathrm{~m}$ diameter and $1.00 \mathrm{~m}$ height, formed of five rings $0.20 \mathrm{~m}$ high connected by duct tape, and placed on digital scales with an irrigation point for each column. The amount of water used by the plants can be monitored in each column by the difference in weight. This platform has already been used to evaluate the tolerance to water stress of cotton (GUIMARÃES et al., 2017a), soybean and common bean (GUIMARÃES et al., 2017b) cultivars.

The experiment took place in a complete randomized block design, in a split plot scheme with four replicates, using 40 soil columns. The main plots consisted of five water regimes and the subplots of two cultivars, Douradão and BRS Soberana, which are tolerant and sensitive to drought, respectively (HEINEMANN et al., 2011). The water regimes consisted of a well-watered treatment (matric potential $\geq-0.025 \mathrm{MPa}$, measured with tensiometers installed at $0.10 \mathrm{~m}$ ) throughout the cycle, and four water restriction treatments. In these treatments, a well-watered condition was maintained until the beginning of panicle emission, phenological stage R3 (41 days after emergence), when water restriction was applied by daily replacement of $20 \%, 40 \%, 60 \%$ and $80 \%$ evapotranspired water at the well-irrigated treatment. It was monitored evapotranspiration by the difference of consecutive readings of the weight of columns, measured with electronic scales.

It was used a clayey Acric Red Latosol (Oxisol), and according to its chemical analysis and crop requirements in greenhouse conditions, four $\mathrm{g}$ column $^{-1}$ of $4-30-16$ commercial formulae were applied at sowing and incorporated into the surface layer of the soil columns. The topdressing followed this same criterion and was performed with two $\mathrm{g}$ column $^{-1}$ ammonium sulfate applied on the soil surface. Ten seeds were sown per column and thinned seven days after emergence, leaving one plant per column.

The root system at the time of the grain harvest in $0.20 \mathrm{~m}$ soil layers from the surface to $1.00 \mathrm{~m}$ deep was evaluated. The separation of the roots from the soil samples occurred with the repeated suspension/decantation method. After separation, the roots were recovered from the supernatant in $0.25 \mathrm{~mm}$ sieves with a tweezer. After purified, the roots were evaluated using the WinRhizo software (Regent Instruments Inc., Québec, Canada), which is an image analysis system specifically designed for washed root measurement in different forms. The root density was obtained by dividing its length, in $\mathrm{cm}$, by the sample volume, in $\mathrm{cm}^{3}$.

The number of tillers per plant, number of grains per panicle, spikelet sterility, 100-grain weight, grain yield per plant, biomass of stems, panicles and leaves per plant, plant and panicle harvest index, water potential, diffusive resistance and temperature of the leaves, evapotranspiration after R3 and water use efficiency (WUE) were also determined. The plant harvest index was obtained by dividing grain yield by the sum of the dry biomass of stems, panicles and leaves and the panicle harvest index by dividing panicle grain weight by panicle dry biomass. Both indices were expressed in percentage. The water potential, diffusive resistance and temperature of the leaves were measured on the superior surface of the apical leaves fully expanded and with good solar exposure, between 13:00 $\mathrm{h}$ and 14:00 h, at 66, 73 and 79 days after emergence, in all subplots of two replicates. The leaf diffusive resistance was measured with a Decagon porometer, model CS-1. The leaf water potential was determined using a 
pressure chamber, Soil Moisture Equipment, model 3005 , and the equipment was installed near the experiment to minimize the time between sample collection and readings of the leaf water potential. The leaf temperature were measured with a Fluke 66 model infrared thermometer. The WUE was determined by the ratio between grain yield and cumulative evapotranspiration of the soil columns, from R3 to harvest.

The analysis of variance and regression, when the effect of water regime was significant, were performed for number of tillers per plant, number of grains per panicle, spikelet sterility, 100-grain weight, grain yield per plant, biomass of stems, panicles and leaves per plant, plant harvest index, and panicle harvest index. Means were compared by Tukey's test, at 5\% probability of significance. For the other variables, only regression equations were adjusted, since they were evaluated just in two replicates. For all analysis, the SAS software (SAS Institute, Cary, NC, USA) was used.

\section{RESULTS AND DISCUSSION}

The simple effects of water regime and cultivars were significant for all evaluated agronomic components, except for spikelet sterility, which did not show a difference between cultivars. The interaction between these factors was significant for grain yield and plant harvest index (Table 1).

Table 1. Summary of the analysis of variance for number of tillers per plant (Tiller), number of grains per panicle (Grain), spikelet sterility (SS), 100-grain weight (GW), grain yield per plant (Yield), biomass of stems (BioStem), panicles (BioPan), and leaves (BioLeaf) per plant, plant harvest index (HIplant) and panicle harvest index (HIpan).

\begin{tabular}{|c|c|c|c|c|c|c|c|}
\hline \multirow[t]{3}{*}{ Variable } & \multicolumn{7}{|c|}{ Source of variation } \\
\hline & Block & $\begin{array}{l}\text { Water regime } \\
\text { (WR) }\end{array}$ & Error a & $\begin{array}{l}\text { Cultivar } \\
\text { (C) }\end{array}$ & $\mathrm{C} \times \mathrm{WR}$ & Error b & $\mathrm{CV}(\%)$ \\
\hline & $\mathrm{DF}^{*}=3$ & $\mathrm{DF}=4$ & $\mathrm{DF}=12$ & $\mathrm{DF}=1$ & $\mathrm{DF}=4$ & $\mathrm{DF}=15$ & \\
\hline Tiller & $27.8^{\mathrm{ns}}$ & $260.4 * *$ & 10.5 & $250.0 * *$ & $10.8^{\mathrm{ns}}$ & 30.4 & 16.3 \\
\hline Grain & $205.1^{\mathrm{ns}}$ & $2129.2 * *$ & 138.6 & $3258.0 * *$ & $770.7^{\mathrm{ns}}$ & 282.6 & 15.3 \\
\hline SS $(\%)$ & $110.8^{\mathrm{ns}}$ & $2687.8 * *$ & 125.5 & $73.0^{\mathrm{ns}}$ & $342.3^{\mathrm{ns}}$ & 144.0 & 27.2 \\
\hline GW (g) & $0.1^{\mathrm{ns}}$ & $0.5^{*}$ & 0.1 & $4.2 * *$ & $0.2^{\mathrm{ns}}$ & 0.1 & 13.9 \\
\hline Yield (g) & $44.1^{\mathrm{ns}}$ & $3988.5 * *$ & 74.7 & $3121.4 * *$ & $249.9 * *$ & 165.0 & 0.9 \\
\hline BioStem (g) & $79.8^{\text {ns }}$ & $1174.3 * *$ & 78.5 & $468.8^{*}$ & $163.3^{\mathrm{ns}}$ & 74.7 & 17.0 \\
\hline BioPan (g) & $0.3^{\mathrm{ns}}$ & $8.2 * *$ & 0.6 & $20.2 * *$ & $4.7^{\mathrm{ns}}$ & 0.3 & 27.0 \\
\hline BioLeaf $(\mathrm{g})$ & $7.0^{\mathrm{ns}}$ & $181.7 * *$ & 21.2 & $128.0 * *$ & $13.0^{\mathrm{ns}}$ & 11.6 & 13.5 \\
\hline HIplant (\%) & $13.3^{\mathrm{ns}}$ & & & & $83.2 * *$ & 10.2 & 10.9 \\
\hline & & $895.7 * *$ & 17.7 & $1480.5^{* *}$ & & & \\
\hline $\operatorname{HIpan}(\%)$ & $13.0^{\mathrm{ns}}$ & $23.2 *$ & 7.2 & $335.7 * *$ & $16.7^{\mathrm{ns}}$ & 8.2 & 3.1 \\
\hline
\end{tabular}

ns, $* *$, *Not significant, significant at $\mathrm{p}<0.01$ and $\mathrm{p}<0.05$ by $\mathrm{F}$ test, respectively.

$* \mathrm{DF}$ - degrees of freedom.

The Douradão cultivar showed $13.8 \%$ fewer tillers than the BRS Soberana but showed $17.9 \%$ more grain with $28.6 \%$ greater weight, resulting in grain yield $62.8 \%$ higher. It also showed less accumulation of carbohydrates in stems and panicle but accumulates more carbohydrates in the leaves. Its plant harvest index was higher by $52.6 \%$ in relation to the BRS Soberana cultivar and it directed the panicle carbohydrate mainly for the formation of grains, presenting panicle harvest index higher by $6.4 \%$ compared to the BRS Soberana cultivar (Table 2). This is a consequence of greater genetic potential and tolerance to water deficit of Douradão cultivar in relation to BRS Soberana, as found by Guimarães et al. (2016a). 
Table 2. Average values of number of tillers per plant, number of grains per panicle, spikelet sterility, 100grain weight, grain yield per plant, biomass of stems, panicles and leaves per plant, plant harvest index and panicle harvest index of the Douradão and BRS Soberana cultivars.

\begin{tabular}{lcc}
\hline \multicolumn{1}{c}{ Variable } & Douradão & BRS Soberana \\
\hline Number of tillers per plant & $31 \mathrm{~b}$ & $36 \mathrm{a}$ \\
Number of grains per panicle & $119 \mathrm{a}$ & $101 \mathrm{~b}$ \\
Spikelet sterility $(\%)$ & $42.8 \mathrm{a}$ & $45.4 \mathrm{a}$ \\
100-grain weight $(\mathrm{g})$ & $2.92 \mathrm{a}$ & $2.27 \mathrm{~b}$ \\
Grain yield per plant $(\mathrm{g})$ & $45.6 \mathrm{a}$ & $28.0 \mathrm{~b}$ \\
Biomass of stems $(\mathrm{g})$ & $47.3 \mathrm{~b}$ & $54.2 \mathrm{a}$ \\
Biomass of panicles $(\mathrm{g})$ & $1.36 \mathrm{~b}$ & $2.78 \mathrm{a}$ \\
Biomass of leaves $(\mathrm{g})$ & $26.9 \mathrm{a}$ & $23.3 \mathrm{~b}$ \\
Plant harvest index $(\%)$ & $35.4 \mathrm{a}$ & $23.2 \mathrm{~b}$ \\
Panicle harvest index $(\%)$ & $96.2 \mathrm{a}$ & $90.4 \mathrm{~b}$
\end{tabular}

Means followed by the same letters do not differ by the Tukey's test at $5 \%$ of significance.

The average number of tillers and grains per panicle and 100-grain weight decreased and spikelet sterility increased with growing water deficit according to the equations: $\mathrm{y}=0.0065 \mathrm{x}^{2}$ $0.6946 x+46.6, R^{2}=0.95^{*} ; y=-0.5352 x+76.2$, $\mathrm{R}^{2}=0.85^{*} ; \mathrm{y}=0.00004 \mathrm{x}^{2}+0.0047 \mathrm{x}+2.176, \mathrm{R}^{2}=$ $0.96^{*}$ and $\mathrm{y}=0.47 \mathrm{x}+81.6, \mathrm{R}^{2}=0.84^{*}$.

The reduction in panicle grain number and increase in spikelet sterility are due to the highly vulnerable to water stress of the formation of pollen grains (SARAGIH et al., 2013). Water stress at 10 days prior to anthesis phase clearly affects pollen germination and pollen tube growth. Reduction of pollen viability and vigor appear to be the cause of a reduction in pollen germinability and retardation in pollen tube growth, resulting in low fertilization and low spikelets production under water stress (SARAGIH et al., 2013). This, in consequence, results in a reduction in grain yield as water deficit increases, as shown in Figure 1a. Heinemann and Stone (2009) related that the occurrence of water deficit close to the flowering period reduces productivity drastically because of an increase in spikelet sterility, which is caused by the minimum water potential in the leaves and in the panicles, developed during the period of water deficit.
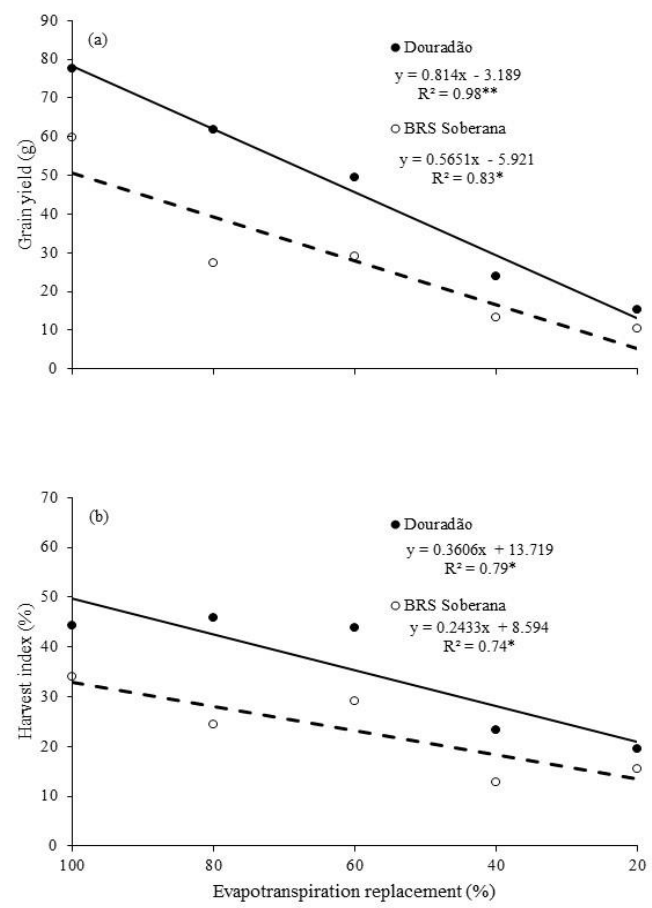
Figure 1. Grain yield per plant (a) and plant harvest index (b) of Douradão and BRS Soberana cultivars as a function of evapotranspiration replacement.

The grain yield decreased linearly with increasing water deficit in both cultivars (Figure 1a). Additionally, the response of the cultivars to the effects of water deficit differ because the genotype vs. water regime interaction was significant (Table 1) and the Douradão cultivar showed higher grain yield than the BRS Soberana in all water regimes. It combines higher yield potential under well-watered conditions and waterstress tolerance, as it showed lower rates of productivity reductions in increasing levels of water deficit, $20.8 \%, 41.6 \%, 62.4 \%$ and $83.3 \%$, in the water regimes $80 \%, 60 \%, 40 \%$ e $20 \%$ of evapotranspiration replacement, respectively, against $22.3 \%, 44.7 \%, 67.0 \%$ and $89.4 \%$ of the BRS Soberana.

These results corroborated those of Guimarães et al. (2016a), which evaluating fortyone genotypes of upland rice for water-stress tolerance, found that Douradão cultivar was in the most productive cluster and the BRS Soberana was in the least productive one under water-stress conditions and that Douradão cultivar showed higher grain yield than the BRS Soberana under well-watered conditions. In addition, Guimarães et al. (2010) related that the most productive genotypes under water deficiency were those with a higher number of grains per panicle and greater 100-grain weight, with lower sterile spikelets, which is the case of Douradão cultivar.

The average biomass of stems and panicles decreased with increasing water deficit according to the equations: $\mathrm{y}=0.3527 \mathrm{x}+29.591, \mathrm{R}^{2}=0.85^{*}$ and $\mathrm{y}=0.0003 \mathrm{x}^{2}-0.0054 \mathrm{x}+1.071, \mathrm{R}^{2}=0.97 *$. The response of the leaf biomass of both cultivars to water deficit did not fit to a linear or polynomial model; however, this variable showed a tendency to decrease as the water deficit increased.

The plant harvest index decreased linearly with increasing water deficit, for both cultivars (Figure 1b). The Douradão cultivar showed higher harvest index than the BRS Soberana in all water regimes. It showed lower rates of reduction in the harvest index in increasing levels of water deficit, $14.5 \%, 29.0 \%, 43.5 \%$ and $58.0 \%$, in the water regimes $80 \%, 60 \%, 40 \%$ and $20 \%$ of evapotranspiration replacement, respectively, against $14.8 \%, 29.6 \%, 44.3 \%$ and $59.1 \%$ of the BRS Soberana. Data suggest that the Douradão cultivar presents more intense carbohydrate distribution for grains than for biomass, both in well-watered conditions such as under water deficit.

The response of the panicle harvest index of both cultivars to water deficit did not fit to a linear or polynomial model; however, this index showed a tendency to decrease as the water deficit increased.

Under well-watered conditions, root density of both cultivars showed almost constant values from surface up to $0.60 \mathrm{~m}$ deep, with increases in the deeper soil layers, due to the barrier provided by the base of the column (Figure 2). However, this increase was not as expressive as that observed under water deficit (application of 20\%, 40\%, 60\% and 80\% evapotranspired water at the well-watered treatment). 


\section{DEFICIT}
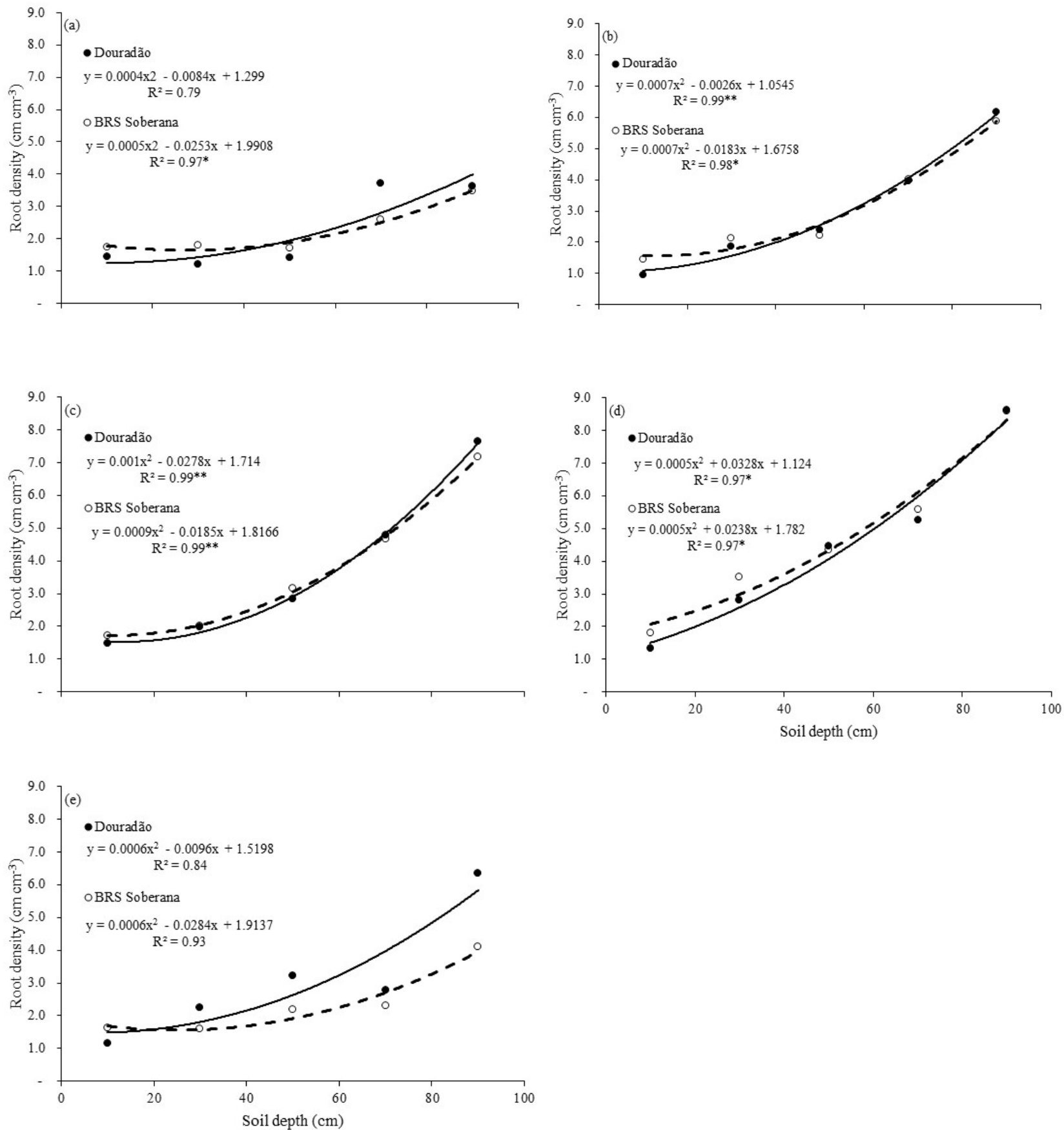

Figure 2. Root distribution in intervals of $0.20 \mathrm{~m}$ from the surface up to $1.00 \mathrm{~m}$ depth of Douradão and BRS Soberana cultivars as a function of evapotranspiration replacement: (a) 100\%, (b) $80 \%$, (c) $60 \%$, (d) $40 \%$ and (e) $20 \%$.

Under water regime of $20 \%$ replacement of evapotranspired water (Figure 2e), the Douradão cultivar, tolerant to water stress, showed higher root density in all soil layers, except in the surficial one, compared to the BRS Soberana cultivar, more susceptible to water deficit. Under the other water regimes (Figure 2a, 2b, 2c and 2d), the cultivars did not show any marked difference in root density.
Guimarães et al. (2011), evaluating 37 cultivars with broad genetic divergence, found that the Douradão cultivar showed root density under water deficit as well as under adequate water availability classified in the intermediary cluster. Thus, it seems that the root system is not the main mechanism of water-stress tolerance for this cultivar. 
The leaf water potential of both cultivars decreased linearly with increasing water deficit (Figure 3a). The Douradão cultivar maintained higher water potential compared to the BRS Soberana, except for the treatment with severe water deficit, suggesting better water uptake capacity or restriction of transpiration. He and Serraj (2012) related that leaf water potential is strongly correlated with spikelet sterility under water stress and that grain yield highly associated with spikelet fertility and leaf water potential. The higher water potential of Douradão cultivar may have contributed for his lower absolute value of spikelet sterility and higher grain yield.

There was a linear increase in leaf diffusive resistance (Figure 3b) and in leaf temperature (Figure 3c) of both cultivars with increasing water deficit. This increase was higher for the Douradão cultivar, suggesting that it has greater stomatal sensitivity, closing their stomata earlier than the BRS Soberana with water deficit evolution, explained thus, the occurrence of higher leaf diffusive resistance and leaf temperature due to the lower transpiration.
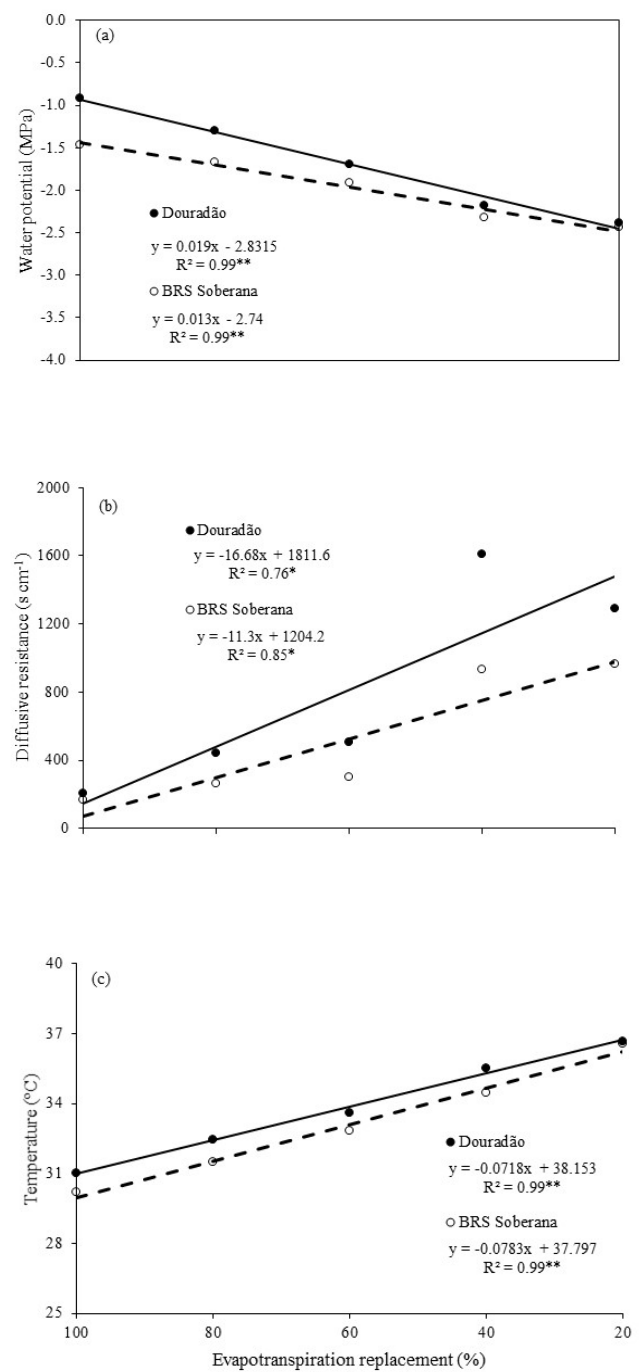

Figure 3. Water potential (a), diffusive resistance (b) and temperature (c) of leaves of the Douradão and BRS Soberana cultivars as a function of evapotranspiration replacement.

Water passing from liquid to gas phase removes heat from the surroundings, thus inducing its cooling. On the other hand, as the stomata close they induce increased leaf resistance and reduced transpiration, resulting in an increase in leaf temperature. This is probably the mechanism of water-stress tolerance of the Douradão cultivar, which gives it better adaptation to environments with water deficit. These observations agree with Heinemann et al. (2011), who stated that the 
Douradão cultivar probably shows early stomatal closure at the beginning of a water deficit period as the basic mechanism for reducing the impact of water stress.
The cumulative evapotranspiration of the soil columns, from R3 to harvest, decreased linearly with increasing water deficit; however, with different intensity for the Douradão and BRS Soberana cultivars (Figure 4a).
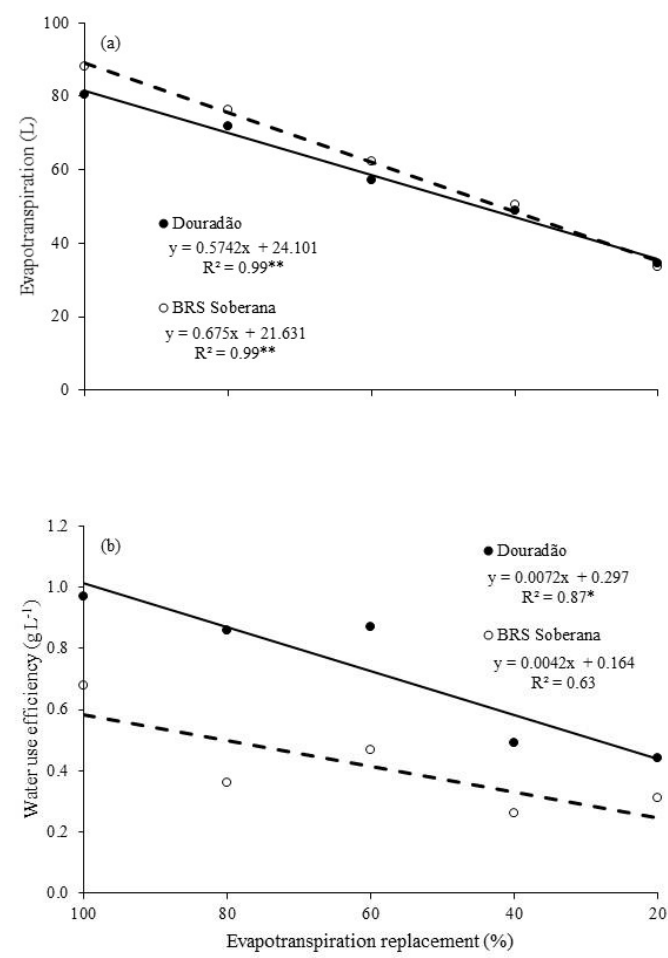

Figure 4. Cumulative evapotranspiration of the soil columns (a) and water use efficiency (b) of Douradão and BRS Soberana cultivars as a function of evapotranspiration replacement.

Each unit of increase in water deficit reduced cumulative evapotranspiration of $0.57 \mathrm{~L}$ in the soil columns with the Douradão cultivar and $0.67 \mathrm{~L}$ in those with the BRS Soberana (Figura 4a). The relative evapotranspiration rate, that is, the relationship between evapotranspiration under water deficit (20\% evapotranspiration replacement) and that observed in well-watered conditions was 0.44 for the Douradão cultivar and 0.39 for the BRS Soberana.

Since the plants totally covered the soil in the columns at the panicle emission stage, transpiration accounted for most of the water lost to the atmosphere. Therefore, the Douradão cultivar showed lower transpiration in well-watered conditions and under moderate water deficit and did not differ from the BRS Soberana in severe water regimes. Guimarães et al. (2016b) also found that rice transpiration decreased with water deficit and Cabuslay et al. (2002) observed that rice cultivars with moderate tolerance to water stress showed higher relative transpiration rates, which confirms the greater tolerance of the Douradão cultivar to water stress in relation to the BRS Soberana.

As the water use efficiency is the ratio between grain yield and evapotranspiration, which vary independently with the water deficit, the data present greater variability, resulting in lower determination coefficients in their adjustment to regression equations (Figure 4b). However, one can observed that water use efficiency for the conversion of carbohydrates in grain production decreased linearly with increasing water deficit in both cultivars, but the Douradão cultivar showed higher values of WUE in all water regimes compared to the BRS Soberana. It seems that the earlier stomatal closure of the Douradão cultivar in relation to the BRS Soberana with water deficit evolution resulted in its better water status, as shown in Figure 3a, expressing in its success in 
partitioning assimilates towards grain yield and improving its WUE compared to the BRS CONCLUSIONS

It is feasible to use the SITIS phenotyping platform and the proposed protocol to evaluate upland rice cultivars for tolerance to water stress.

Under water deficit, the drought-tolerant cultivar Douradão restricts water loss through transpiration and shows harvest index, grain yield and water use efficiency higher than the BRS Soberana cultivar.

\section{REFERENCES}

ARAUS, J. L.; CAIRNS, J. E. Field highthroughput phenotyping: the new crop breeding frontier. Trends in Plant Science, v. 19, n. 1, p. 52-61, 2014. https://doi.org/10.1016/j.tplants.2013.09.008.

CABUSLAY, G. S.; ITO, O.; ALEJAR, A. A. Physiological evaluation of responses of rice (Oryza sativa L.) to water deficit. Plant Science, v. 163, n. 4, p. 815-827, 2002. https://doi.org/10.1016/S0168-9452(02)00217-0.

COMAS, L. H.; BECKER, S. R.; CRUZ, V. M. V.; BYRNE, P. F.; DIERIG, D. A. Root traits contributing to plant productivity under drought. Frontiers in Plant Science, v. 4, n. 442, p. 1-16, 2013. https://doi.org/10.3389/fpls.2013.00442.

GUIMARÃES, C. M.; CASTRO, A. P. de; STONE, L. F.; OLIVEIRA, J. P. de. Drought tolerance in upland rice: identification of genotypes and agronomic characteristics. Acta Scientiarum. Agronomy, v. 38, n. 2, p. 201-206, 2016 a. http://dx.doi.org/10.4025/actasciagron.v38i2.27164.

GUIMARÃES, C. M.; STONE, L. F.; BRITO, G. G. de; HEUERT, J. Evaluation of water-stress tolerance of Acala SJ 2 and Auburn 2 cotton cultivars in a phenotyping platform. Revista Ambiente \& Água, v. 12, n. 4, p. 629-642, 2017a. http://dx.doi.org/10.4136/ambi-agua.2105.

GUIMARÃES, C. M.; STONE, L. F.; CASTRO, A. P. de; MORAIS JÚNIOR, O. P. de. Physiological parameters to select upland rice genotypes for tolerance to water deficit. Pesquisa Agropecuária Brasileira, v. 50, n. 7, p. 534-540,
Soberana.

2015. $204 X 2015000700003$.

http://dx.doi.org/10.1590/S0100-

GUIMARÃES, C. M.; STONE, L. F.; LORIEUX, M.; OLIVEIRA, J. P. de; ALENCAR, G. C. de O.; DIAS, R. A. A. Infrared thermometry for drought phenotyping of inter and intra specific upland rice lines. Revista Brasileira de Engenharia Agrícola e Ambiental, v. 14, n. 2, p. 148-154, 2010. http://dx.doi.org/10.1590/S141543662010000200005.

GUIMARÃES, C. M.; STONE, L. F.; OLIVEIRA, J. P. de; RANGEL, P. H. N.; RODRIGUES, C. A. P. Sistema radicular do arroz de terras altas sob deficiência hídrica. Pesquisa Agropecuária Tropical, v. 41, n. 1, p. 126-134, 2011. http://dx.doi.org/10.5216/pat.v41i1.8460.

GUIMARÃES, C. M.; STONE, L. F.; RANGEL, P. H. N.; SILVA, A. C. de L. Tolerance of upland rice genotypes to water deficit. Revista Brasileira de Engenharia Agrícola e Ambiental, v. 17, n. 8, p. 805-810, 2013. http://dx.doi.org/10.1590/S141543662013000800001 .

GUIMARÃES, C. M.; STONE, L. F.; SILVA, A. C. de L. Evapotranspiration and grain yield of upland rice as affected by water deficit. Revista Brasileira de Engenharia Agrícola e Ambiental, v. 20, n. 5, p. 441-446, 2016b. http://dx.doi.org/10.1590/1807-

1929/agriambi.v20n5p441-446.

GUIMARÃES, C. M.; STONE, L. F.; ZITO, R. K. Susceptibility of common bean and soybean to water stress evaluated at the SITIS phenotyping platform. Bioscience Journal, v. 33, n. 4, p. 871880, 2017b. http://dx.doi.org/10.14393/BJv33n4a2017-36731.

HE, H.; SERRAJ, R. Involvement of peduncle elongation, anther dehiscence and spikelet sterility in upland rice response to reproductive- stage drought stress. Environmental and Experimental Botany, v. 75, n. 1, p. 120-127, 2012. https://doi.org/10.1016/j.envexpbot.2011.09.004.

HEINEMANN, A. B.; STONE, L. F. Efeito da deficiência hídrica no desenvolvimento e rendimento de quatro cultivares de arroz de terras 
altas. Pesquisa Agropecuária Tropical, v. 39, n. 2, p. 134-139, 2009.

HEINEMANN, A. B.; STONE, L. F.; FAGERIA, N. K. Transpiration rate response to water deficit during vegetative and reproductive phases of upland rice cultivars. Scientia Agricola, v. 68, n. 1, p. 24-30, 2011. http://dx.doi.org/10.1590/S010390162011000100004.

KUMAR, A.; DIXIT, S.; RAM, T.; YADAW, R. B.; MISHRA, K. K.; MANDAL, N. P. Breeding high-yielding drought-tolerant rice: genetic variations and conventional and molecular approaches. Journal of Experimental Botany, v. 65, n. 21, p. 6265-6278, 2014. http://doi.org/10.1093/jxb/eru363.
MIR, R. R.; ZAMAN-ALLAH, M.; SREENIVASULU, N.; TRETHOWAN, R.; VARSHNEY, R. K. Integrated genomics, physiology and breeding approaches for improving drought tolerance in crops. Theoretical and Applied Genetics, v. 125, n. 4, p. 625-645, 2012. http://doi.org/10.1007/s00122-012-1904-9.

SARAGIH, A. A.; PUTEH, A. B.; ISMAIL, M. R.; MONDAL, M. M. A. Pollen quality traits of cultivated (Oryza sativa L. ssp. indica) and weedy (Oryza sativa var. nivara) rice to water stress at reproductive stage. Australian Journal of Crop Science, v. 7, n. 8, p. 1106-1112, 2013. 